on a standard above the body, and the control column hangs from this, convenient for the pilot's hand. Its movements are about $5^{\circ}$ fore and aft and rather less laterally. It can be locked forward in such a position that it is impossible to put the machine into anything but a climbing attitude when leaving the ground. Normal landings are made by coming in to about $10 \mathrm{ft}$. above the ground at lowest gliding speed, lifting the nose, and opening up full engine power, which drives the tail down. When the tail wheel touches the ground the engine is shut off, lift is lost, and the front of the machine falls. Thus the forward momentum of the machine is negligible, and it stops practically dead. Landings without engine, that is, the most probable type of forced landing, are not so slow, and have to be made as with the conventional aeroplane, with a forward speed of about 25 miles per hour, at which the rotors have just sufficient lift at the gliding angle necessary to maintain this. The pull-up run is then about 50 yards. Full control is retained at this speed. An interesting secondary point has arisen from the fact that owing to the machine's great speed range, 25-120 miles per hour, it is inefficient at one end of this unless fitted with a variable pitch propeller. At present there is no suitable small-power airscrew available, development of these having always been directed towards those for high-power supercharged engines.

\section{Micro-Methods for the Determination of Helium}

IN the first of a course of three lectures arranged by the University of London and delivered on November 14 at the Imperial College, South Kensington, Prof. Fritz Paneth, until lately director of the Chemical Institute at Königsberg, described the micro-methods now available for the determination of helium. The special experimental technique evolved in the Königsberg laboratories permits the qualitative detection of so small a quantity of helium as $10^{-9}-10^{-10}$ c.c., and the quantitative estimation, with an uncertainty of about 1 per cent, of $10^{-5}$ c.c. Prof. Paneth discussed briefly the various problems in the solution of which this refined radium technique has been or may be employed - such as the concentration of helium in the stratosphere, the age of minerals, particularly those derived from the Kimberley diamond pipes, the origin of meteorites, and sundry questions connected with natural or artificial transmutation. The further lectures of this course, to be delivered on November 21 and 28, will be devoted to the consideration of the age and origin of meteorites, and the chemical detection of transmutation.

\section{The Newcomen Society}

THE annual general meeting of the Newcomen Society was held on November 8 at the Institution of Structural Engineers. The report stated that on October 1, 1933, the membership was 323, while during the year eight meetings had been held in London, two in New York, and one in London in conjunction with the Omnibus Society. As the outcome of one of the papers read, a Shetland water mill has been secured for the Science Museum, while through the paper by $\mathrm{Mr}$. H. W. Dickinson on "Jolliffe and Banks, Contractors", the firm which built Waterloo, Southwark and London Bridges, the tomb of Sir Edward Banks in Chipstead Churchyard, Surrey, has been restored at the expense of $\mathrm{Mr}$. J. J. M. Edwards, chairman of the Bridge House Estates Committee of the City of London. The Society took an active part in the bicentenary celebrations of Arkwright and Priestley and the centenary commemoration of Trevithick. During the year, an Extra Publication No. 3, and vol. 11 of the Transactions have been issued.

Ar the conclusion of the business of the annual meeting of the Newcomen Society, a lecture was given by Mr. S. B. Hamilton on "The Place of Sir Christopher Wren in the History of Structural Engineering", the lecture being illustrated with many lantern slides of St. Paul's Cathedral. Prior to Wren's time, the only work on the strength of materials of which any record exists was that of Leonardo da Vinci, and the "Dialogues" of Galileo. The latter were discussed at the early meetings of the Royal Society, but Wren does not appear to have been interested in them. Neither did Wren write anything on materials, although he made a profound study of buildings, and exercised exceptional ingenuity in the combination of structural forms. His reports on old St. Paul's, Salisbury Cathedral and Westminster Abbey contained many interesting criticisms on their construction and the way the heavy loads were taken. What calculations Wren made of loads and stresses is not known; indeed exact calculation would have been useless to a designer who repeatedly altered his plans as the work progressed. One subject he was greatly interested in was the treatment of the arch, which was also dealt with by Hooke and David Gregory. Of great interest was Mr. Hamilton's review of the steps by which Wren was led to the construction of the dome of St. Paul's as it is seen to-day. This is the work which gives Wren enduring fame as a structural engineer. Though through the failure to provide adequately for shear, defects arose in the counterforts, necessitating the extensive repairs of a few years ago, yet the marvel is not that defects occurred, but that such a stupendous mass of intricately balanced masonry was ever made to hold together.

\section{New Broadcasting Station at Budapest}

THE authorities responsible for the broadcasting service in Hungary have always kept abreast of the latest developments in wireless technique; indeed, Budapest claims the distinction of being the first town in the world to inaugurate a system of broad. casting over wires so early as 1893 . Budapest will again come into prominence in the near future on the opening of its new broadcasting station, with a transmitter power of $120 \mathrm{kw}$, and an aerial mast which is claimed to be the highest in the world. A brief description of this station and a photograph of the new mast is given in World Radio of November 10. 